\title{
LANGUAGE CHOICE OF RESIDENTS OF KAMPUNG WARNA-WARNI MALANG TO THE TOURISTS
}

\author{
Ismatul Khasanah ${ }^{1, *}$, Roosi Rusmawati $^{2}$, Khilmi Mauliddian ${ }^{3}$, Arif Nur Rohman Hakim ${ }^{4}$ \\ ${ }^{1}$ Department of Languages and Literature, Faculty of Cultural Studies, Universitas Brawijaya, Malang 65145, \\ Indonesia \\ ${ }^{2}$ Department of Languages and Literature, Faculty of Cultural Studies, Universitas Brawijaya, Malang 65145, \\ Indonesia \\ ${ }^{3}$ Department of Languages and Literature, Faculty of Cultural Studies, Universitas Brawijaya, Malang 65145, \\ Indonesia \\ ${ }^{4}$ Department of Languages and Literature, Faculty of Cultural Studies, Universitas Brawijaya, Malang 65145, \\ Indonesia
}

\section{A RTICLE INFO}

Keywords:

Language choice

Kampung Warna-Warni

Residents

Tourists

Sociolinguistics

Article History:

Received: 25/02/2020

Accepted: 16/11/2020

Available Online:

30/11/2020

\begin{abstract}
A B S T RACT
Residents' language choice of Kampung Warna - Warni Malang towards tourists is an interesting study as the linguistics phenomenon from a sociolinguistic's perspective affects both social and cultural life there. The study aims to describe the resident's language choice through daily interaction between the residents and the tourists. The writer used a qualitative method to provide a general description of the phenomenon as clearly as possible without any interference to observed study subjects. This research was a sociolinguistic study based on the language phenomena that occurred in the tourism spot which is originally considered as slums in recent years before went through many beautifications from many parties. The result found that the residents tend to use code-switching from Javanese, both Ngoko and Krama form, and Indonesian to converse with domestic tourists. Meanwhile, the locals tend to shy away from conversing with international tourists except for a simple greeting, a simple gesture of navigating direction, and a simple yes or no question due to the language barrier.
\end{abstract}

2442-305X / C 2020 The Authors, this is open access article under the (CC-BY-NC) license (https://creativecommons.org/licenses/by-nc/4.0/), DOI: 10.19105/ojbs.v14i2.3086

\footnotetext{
$\overline{\text { * Corresponding Author: }}$

Email address: ismatulkh@ub.ac.id (I. Khasanah)
}

\section{A. Introduction}

The use of language cannot be separated from daily life as it becomes a vital core in every aspect of life as a communication device. Every person uses language to express and grasp intention and desire to and from another person.
The language also helps to form and develop mindset and reasoning to lead to an inevitable desired outcome. Mustikawati said that language as a communication tool could be used to reach different goals and interests. ${ }^{1}$

${ }^{1}$ Dyah Atiek Mustikawati, "Alih Kode dan Campur 
The recent development of language phenomena cannot be separated from the human condition. It is no surprise that the form of language is very closely related to the behavior of the social and cultural environment. According to Sholihatin, the study of the language without relating it to the community will rule out some important and interesting aspects. $^{2}$ Mardikantoro said that the form of language cannot be separated from social and cultural factors. ${ }^{3}$ Due to that fact, sociolinguistics presence becomes an important device to dissect the language phenomena in society.

\section{According to Ngalim,} Sociolinguistics is an interdisciplinary branch of linguistics that studies language variety and functions which are closely related to the heterogeneous community of language users. ${ }^{4}$ Also, Wijana dan Rohmadi said that sociolinguistics perceives language as a society's product, not as a product of an individual person. ${ }^{5}$ Hence, the use of language

Kode antara Penjual dan Pembeli (Analisis Pembelajaran Berbahasa melalui Studi Sosiolinguistik)," Jurnal Dimensi Pendidikan dan Pembelajaran 2, no. 2 (2016): 23, https://doi.org/10.24269/dpp.v2i2.154.

2 Anis Sholihatin, "Pemilihan Kode pada Masyarakat Keturunan Arab di Noyontaan, Kota Pekalongan: Kajian Sosiolinguistik" (Thesis, Universitas Diponegoro, 2008), 12.

3 Hari Bakti Mardikantoro, "Pilihan Bahasa Masyarakat Samin dalam Ranah Keluarga," Jurnal Humaniora 24, no. 3 (2012): 345-57, https://doi.org/10.22146/jh.1376.

4 Abdul Ngalim, Sosiolinguistik Suatu Kajian Fungsional dan Analisisnya (Surakarta: PBSID FKIP UMS, 2013), 28.

${ }^{5}$ I. Dewa Putu Wijana and Muhammad Rohmadi, Sosiolinguistik: Kajian Teori dan Analisis (Yogyakarta: Pustaka Pelajar, 2013), 7. covers both linguistic and non-linguistic factors.

An example of that is an interaction between language speakers has to be related to their surrounding situation and condition to reach a certain result or conclusion. It shows that the use of language is affected by external aspects; the social situation and condition, as much as it is affected by internal aspects of linguistic. Thus, sociolinguistics is a study that deals with the interaction between speakers, the variations of the language, the various factors of both linguistic and non-linguistic which determine which variation of language will be used, as well as various forms of language exists or spoken in society. ${ }^{6}$

One of the many phenomena that are often being chosen as the object of study in sociolinguistics is the phenomena of language choice. Language choice appears due to the bilingual or multilingual nature of the people in a certain society. Chaer dan Agustina said that bilingual is a person's skill to use two languages to converse, while multilingual is when a person can use more than two languages. $^{7}$ Meanwhile, Widianto and Zulaeha argue that some linguists use the term of language choice as a form of rationality from the implications of bilingual

\footnotetext{
${ }^{6}$ Umi Kholidah, "Pemertahanan Bahasa Jawa pada Interaksi Siswa dan Guru dalam Pembelajaran Kajian Sosiolinguistik di MTS Al-Hikmah Pasir Demak," Ranah: Jurnal Kajian Bahasa 4, no. 2 (2015): 107, https://doi.org/10.26499/rnh.v4i2.27.

${ }^{7}$ Abdul Chaer and Leonie Agustina, Sosiolinguistik Perkenalan Awal, Revision (Jakarta: PT Rineka Cipta, 2010), 85.
} 
or multilingual persons' emergence. ${ }^{8}$ Multilingual also often be referred to as society consists of many languages being spoken by its people. ${ }^{9}$ Besides, Wardhani and others said that the language choice is in the context of the situation used in communication-related social and cultural backgrounds. $^{10}$ Thus, bilingualism or multilingualism can be achieved by choosing the language, as other factors contributing to the process are dependent on society's condition.

Based on the background above, the writer decides the phenomena of language choice in kampung WarnaWarni Jodipan (KWJ) Malang. KWJ is a tourism spot that is previously an area that some people called as slums. As a tourism spot, KWJ attracts many tourists of local, domestic, and international origin.

Based on the origin of KWJ, a brief observation shows that Kampung Jodipan before underwent renovation and beautification, is inhabited by Javanese speakers with Malang dialect or is often referred to as Jawa Malangan. After the change happened, the residents of Kampung Jodipan have to encounter and interact with visitors or tourists. The interaction between the resident of $\mathrm{KWJ}$

\footnotetext{
${ }^{8}$ Eko Widianto dan Ida Zulaeha, "Pilihan Bahasa dalam Interaksi Pembelajaran Bahasa Indonesia bagi Penutur Asing," Seloka: Jurnal Pendidikan Bahasa dan Sastra Indonesia 5, no. 2 (2016): 126 https://doi.org/10.15294/seloka.v5i2.13074.

9 David Crystal, A Dictionary of Linguistics and Phonetics (New Jersey: John Wiley \& Sons, 2011), 228.

${ }^{10}$ Pramika Wardhani, "Wujud Pilihan Bahasa dalam Ranah Keluarga pada Masyarakat Perumahan di Kota Purbalingga," KREDO: Jurnal IImiah Bahasa dan Sastra 1, no. 2 (2018): 92, https://doi.org/10.24176/kredo.v1i2.2147.
}

and the tourist becomes a catalyst in which language choosing has happened. Thus, the writer's object of study is the phenomena of language choice that is occurred in KWJ.

KWJ located in Jodipan which is included in the sub-district of Blimbing Malang, covering almost 50-hectare land. Jodipan is bordered by Polehan and Kesatrian area to the north, Kedungkandang sub-district to the east, Kotalama to the south, and Sukoharjo to the west.

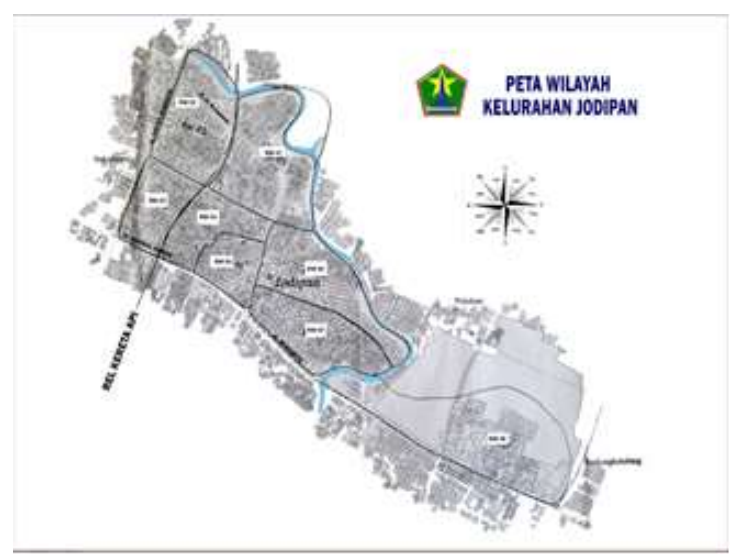

Fig. 1. Map of Jodipan Disctrict ${ }^{11}$

Geographically, KWJ is a largely populated area located on Brantas river bank, which also can be seen directly from Brantas bridge. KWJ is located on a slope of the Brantas riverbank, and the populated area stops at the edge of the river itself. $\mathrm{KWJ}$ is populated by more than a hundred households, which mostly consist of newcomers of Madurese (Madura) descendants. Before being renovated to be a tourism spot, $\mathrm{KWJ}$ is an

\footnotetext{
11 Kelurahan Jodipan, "Peta Wilayah Kelurahan Jodipan," accessed October 8, 2020, https://keljodipan.malangkota.go.id/profil/petawilayah-kelurahan-jodipan/.
} 
area some people might have called slums. According to the data gained from KOTAKU (Kota Tanpa Kumuh), Kampung Jodipan is considered one of the twentynine slums of Malang. Eviction has been a constant threat to the people in Kampung Jodipan before it is renovated into KWJ. Nowadays, it is considered one of the most popular urban tourism spots in Malang, serving hundreds of tourists a day, even reaching the number of thousands on certain days.

Labov said that sociolinguistics is a study of language focuses on the relation of the language itself to the society of speakers, so the view of a language will not be limited to the discipline of a language, rather it considers other factors affecting the language to be able to view a language as a discipline and a phenomenon as an inseparable pair. ${ }^{12}$

Language choice is an act of choosing a specific language to be spoken in general society. ${ }^{13}$ In other words, language choice happened because of the multilingual nature of a society possessing the whole of codes, including language, dialect, variation, and style in its daily social interaction. Language choice does not only deal with linguistic factors; instead, it also deals with the phenomena of social, culture, psychology, and other contributing factors. Rokhman said there are three categories in language choice, namely (1) intra-

12 William Labov, Sociolinguistics Patterns (Philadelphia: University of Pennsylvania Press, 1972), 293.

13 Ralph Fasold, The Sociolinguistics of Society (Oxford: Basil Blackwell Ltd, 1984), 180. language variation; (2) code-switching); and (3) code-mixing. ${ }^{14}$

According to Evin-Tripp, four main factors are affecting the process of language choice in social interaction. First are the setting and the situation of interaction. The setting refers to the time and place where the interaction happens, while the situation refers to the interaction's nuance. ${ }^{15}$ Then, there is the Participant of the interaction factor. This factor focuses on things like age, sex, profession, social and economic status, the relationship between the speakers, the topic of the interaction, the theme, and the topic of interaction affect the process of language choice. It also helps to determine the pattern of the process of language choice by determining the most common theme and topic used in an interaction in a certain society.

And the last is the function of the interaction. It deals with the goal of interaction, such as information, rejection, appeal, and daily mundane conversation, which all can affect language choice.

Four previous studies are conducted, two of which deals with language choice in society, and the rest deals with a society's traditional language. The first study of language choice is done by Mardikantoro's Pilihan Bahasa Masyarakat Samin dalam Ranah

14 Fathur Rokhman, Sosiolinguistik: Suatu Pendekatan Pembelajaran Bahasa dalam Masyarakat Multikultural (Yogyakarta: Graha IImu, 2013), 25

15 S. Ervin-Tripp, "Sociolinguistics Rules of Address," in Sociolinguistics, by J.B. Pride and Janet Holmes (London: Penguin Books, 1972), 92100. 
Keluarga. ${ }^{16}$ His study adopted the qualitative method as it produces descriptive data in the form of written data. The study suggested that the Samin people communicate with each other using Ngoko Javanese and Madya Javanese by code changing and codemixing in the realm of the daily household. The second previous study is a qualitative study done by Niswa and Mukhlish entitled Pilihan Bahasa dalam Masyarakat Multilingual di Kemujan Karimunjawa Jepara. ${ }^{17}$ The result of this study consists of three results.

First, the linguistic repertoire in the multilingual society of Kemujan consists of Javanese Language, Language of Bugis people or Buginese language, Indonesian language, and Madurese language. The percentages are as follows.

1. $40 \%$ of people in Kemujan only speak one language, which is the Javanese language $(20 \%)$, the Buginese language (15\%), and the Madurese language $(5 \%)$.

2. $30 \%$ of Kemujan people are bilingual, Javanese language and Buginese language (10\%), Javanese language and Indonesian language (10\%), Javanese language, and Madurese language $(5 \%)$, and Buginese language and Indonesian language (5\%).

\footnotetext{
${ }^{16}$ Mardikantoro, "Pilihan Bahasa Masyarakat Samin dalam Ranah Keluarga," 345.

17 Lailatun Niswa dan Mukhlish, "Pilihan Bahasa dalam Masyarakat Multilingual di Kemujan Karimunjawa Jepara," Caraka 3, no. 2 (15 Juni 2017): 110-26, https://doi.org/10.30738/caraka.v3i2.1893.
}

3. $30 \%$ of the people of Kemujan has more than two languages; Indonesian language, Buginese language, Madurese language (15\%), Javanese language, Indonesia language, Madurese language (10\%) and Javanese language, Indonesia language, Madurese language, and Indonesian language (5\%).

Second, the pattern of language usage in the people of Kemujan can be differentiated by the realm in which the interaction revolves around; (a) Javanese language and Indonesian language are the most common language in the realm of family, neighbor, and transaction. (b) Javanese language and Indonesian language are the most common language in education, religion, and government.

Lastly, the language choice process is affected by the social variable. Educated individuals mostly use the Javanese language and Indonesian language $(22 \%)$. Working-class mostly uses the Javanese language (25\%). The gender variable mostly uses the Javanese language (20\%). Age variable mostly uses the Javanese language (17\%).

The third previous study is about the language shift of traditional language of Lampung happened in bandar Lampung which is done by Putri entitled Pergeseran bahasa Daerah Lampung pada Masyarakat Kota Bandar Lampung. ${ }^{18}$ This qualitative study showed that Lampung's

\footnotetext{
${ }^{18}$ Nandita Wana Putri, "Pergeseran Bahasa Daerah Lampung pada Masyarakat Kota Bandar Lampung," PRASASTI: Journal of Linguistics 3, no. 1 (2018): 83-97, https://doi.org/10.20961/prasasti.v3i1.16550.
} 
traditional language is slowly shifted, and if there is no step toward language preservation, the language could become an extinct language.

Lastly, Apriliyani and Rokhman conducted research entitled Strategi Pilihan Bahasa Pengusaha Industri Banyumas. $^{19}$ This study focuses on the strategy of language choice in the realm of Industrial business used by its businessman. The result is that there are processes of language choice like codeswitch and code-mix.

The writer uses the same object as the first, second, and fourth studies, focusing on the language choice phenomena while sharing the same goal with the third one to gain the full picture of the traditional language's condition. The writer's study's different point is it focuses on the place of the conducted research, a tourism spot. Thus, the writer focuses on the language choice of the resident of KWJ toward the tourists and the interaction between the two parties to gain the full picture of the language situation there.

There are two things that the writer is attempting to discuss. The first one is the form of language choice of KWJ residents toward visiting tourists, and the second is the process of interaction happening between the KWJ residents and the tourists.

\footnotetext{
19 Nurul Apriliyani dan Fathur Rokhman, "Strategi Pilihan Bahasa Pengusaha Industri di Kecamatan Ajibarang Kabupaten Banyumas," Seloka: Jurnal Pendidikan Bahasa dan Sastra Indonesia 5, no. 2 (2016): 184-91, https://doi.org/10.15294/seloka.v5i2.13082.
}

\section{B. Method}

This research used a qualitative approach that focuses on the language choice of KWJ residents toward tourists. This method aims to produce descriptive data in written or oral form from the people and observed behavior in a certain phenomenon. ${ }^{20}$ The subject of study was the spoken words of the interaction of residents of $\mathrm{KWJ}$ with the tourists.

The techniques used were simak, libat, and cakap. Therefore, the researcher observed the conversation whilst done nothing to affect the flow of conversation. ${ }^{21}$ Thus, the researcher observed without interfering with the conversation between the resident and the tourist.

The goal of this study was a systematic and factual solution based on data from residents of $\mathrm{KWJ}$ toward tourists. Thus, the researchers presented the data, analyze the data, and interprets the data. The data presentation were done informally as Sudaryanto in Kesuma stated that presenting the data analysis can be done using ordinary words. ${ }^{22}$

There were three data-gathering steps: a) pre-research, b) field observation, and c) interview and documentation. Then, the researcher documented the conversation by using

\footnotetext{
${ }^{20}$ Lexy J. Moleong, Metodologi Penelitian Kualitatif (Bandung: Remaja Rosdakarya, 2014), 4.

21 Hari Bakti Mardikantoro, "Bentuk Pergeseran Bahasa Jawa Masyarakat Samin dalam Ranah Keluarga," LITERA 11, no. 2 (2012): 208, https://doi.org/10.21831/ltr.v11i2.1062.

22 Tri Mastoyo Jati Kesuma, Pengantar (Metode) Penelitian Bahasa (Yogyakarta: Carasvatibooks, 2007), 71
} 
notes and a video recorder. The study was conducted in Kampung Warna-Warni Jodipan (KWJ) Malang.

\section{Results}

\section{Form of Language Choice toward Tourists}

As KWJ has become a widely known tourism spot, KWJ residents have to encounter waves of domestic and international tourists. To be understood by the tourists, KWJ residents, who mostly speak Jawa Malangan, have to find a way to communicate with them. The effort of KWJ residents to be understood by the tourists is shown in their interaction with each other.

There are four entrances to the $\mathrm{KWJ}$, which are provided to the tourists as well as serving as a ticket booth for the entrance pass. The charge is only three thousand rupiah per-person for one-time entry. The ones who are in charge of those entrances are KWJ residents. The first encounter happens at the ticket booth as they have to do the ticket transaction.

The tourists then will enter the tourism area and find there are many shops within which are also being managed by the residents as many of them are using their terraces to establish the business. The shops vary from general shops for locals, snack shops, eateries, and gift shops. in those shops, the residents of KWJ will encounter many interactions with tourists. Because the entire KWJ has been decorated and painted in such a colorful way, the tourists tend to walk around the entire complex. The tourists will encounter many residents on the way and interact with them in some ways as they have to walk among the residents' houses and frequent stops to take pictures. The interactions mostly consist of greeting when tourists see the residents on their terraces or passing each other on the way. Thus, there are three most likely places to find any interaction between the tourists and the residents; the entrances, the shops, and the well-decorated area of the complex where the tourists often stop for pictures.

These are the examples of the interaction in areas where the language choice phenomena happened.

\section{a. The Ticket Booth}

Context: The resident in charge of serving tourists seeking to enter KWJ.

\section{1) Conversation 1}

Resident : "Pinten Mas?"/ "How many, Sir?" (Asking about how many to enter in Krama Javanese)

Tourist : "Tiga, Bu." / "Three persons, Maam." (Answering in Indonesian)

Resident : "Sembilan ribu, Mas. Niki stikernya." / "Nine thousand, Sir. These are the tickets." (Giving response in code-mixing for Indonesian and Krama Javanese).

\section{2) Conversation 2}
Resident : "Berapa orang?" / "How many people to enter?" (Asking in casual Indonesian)
Tourist : "Dua" / "Two" (Answering in casual Indonesian)


Resident : "Dari mana?" / "Where are you from?" (Asking in casual Indonesian)

Tourist : "Surabaya" (The capital of East Java)

Resident : "Monggo" / "Please enter." (Code shift to Krama Javanese as the resident finds out that the tourists are from Javanese speaking society)

\section{3) Conversation 3}

Tourist : "Tiketnya berapa, Bu?" / "How much do the ticket cost, Mam?" (The tourist is asking first in Indonesian)

Resident : "Satu orang tiga ribu. Berapa orang, Bu?"/ "Three thousand for each person. How many persons, Mam?" (Answering and asking in Indonesian)

Tourist : "Empat orang" / "Four persons" (Answering in Indonesian)

Resident : "Dua belas ribu." / "Twelve thousand Rupiah." (Responding in Indonesian)

\section{4) Conversation 4}

Tourist : "Berapa?" / "How much?" (Asking for the ticket price in casual Indonesian)

Resident : "Lima? Lima belas ribu." / "Five persons? Fifteen thousand." (Answering in Indonesian)

Tourist : "Terima kasih." / "Thank you." (Expressing in Indonesian)

\section{5) Conversation 5}

Resident : "Silahkan, berapa mas?" / "Please here, for how many, Sir?" (Asking in Indonesian)
Tourist : "Gangsal, Bu" / "Five please, Maam." (Answering in Krama Javanese)

Resident : "Lima belas ribu, Mas. Ini tiketnya. Matur nuwun, nggeh." / "Fifteen thousand, Sir. Here are the tickets. Thank you." (Code-mixing between Indonesian and Krama Javanese)

The conversations above are examples of the process of language choice by the KWJ resident conducting conversation and transaction with tourists at the entrances. In conversation 1, the resident appeared to use code-mixing between Krama Javanese and Indonesian. The resident assumed the tourist is Javanese. Therefore, the Javanese question of "pinten mas" is used. Then as the tourist responded in the correct answer of how many people are with the tourist, albeit using Indonesian for the answer, the resident's assumption of the tourist being Javanese is confirmed, although for some reason, the last response of the resident appears to be code-mixing between Krama Javanese and Indonesian.

The second conversation shows that the resident is starting the conversation safely by using the Indonesian language as the resident is still not sure whether the tourist is Javanese. Only after the resident asked about the tourist's origin, then the resident responded in Krama Javanese.

The resident used code switch from Indonesian to Krama Javanese only after confirming the tourist's origin.

Next, from the conversation 3, 4, and 5 , the resident used full Indonesian. 
The resident used full Indonesian because the tourist uses Indonesian first to ask the question. The resident was adapting to the situation and proceeded to use full Indonesian to talk with the tourist.

Based on those five conversation data on the ticket booth, it can be seen that the form of language choice used by the resident can be separated into two patterns; mixed and full form of language choice. In the mixed form, the language choices in use are Indonesian and Krama Javanese, as for the full form the language used is only Indonesian.

Some phenomenons where different languages are being used in the same context and situation were found in those conversations. However, this phenomenon does not make a hindrance out of the language differences to conduct a conversation. It caused by a certain understanding and tolerance of both parties to different languages even though the information in a different language is not necessarily be understood fully by the partner. As supported by Kholidah and Haryadi stated, a code-mixing happening makes a situation where both of the speaker and its partner seem to master each other's language. ${ }^{23}$

\section{b. Shops}

Context: the resident acts as the seller serving the tourist as the customer or potential customer.

23 Umi Kholidah and Haryadi Haryadi, "Wujud Pilihan Kode Tutur Mahasiswa Aceh pada Ranah Pergaulan di Semarang," Seloka: Jurnal Pendidikan Bahasa dan Sastra Indonesia 6, no. 2 (September 4 2017): 208-217,

\section{1) Conversation 1}

Tourist : "Bu, Kopi pinten?" / "How much are the coffee, Mam?" (Asking in Krama Javanese)

Resident : "Empat ribu." / "Four thousand." (Answering in Indonesian)

\section{2) Conversation 2}

Tourist : "Es wonten, Bu?" / "Do you have any cold drinks, Maam?" (Asking in Krama Javanese)

Resident : "Es apa?" / "What kind of cold drink do you want?" (Answering in Indonesian)

Tourist : "Es Nutrisari, berapa?" / "How much do Es Nutrisari cost?" (Asking in Indonesian)

Resident : "Lima ribu." / "Five thousand." (Answering in Indonesian)

\section{3) Conversation 3}

Tourist : "Pinten Bu kopine?" / "How much do the coffees cost?" (Asking in mixed style between Ngoko Javanese and Krama Javanese)

Resident : "Sekawan ewu, Mas." / "Four thousand, Sir" (Answering in Krama Javanese)

\section{4) Conversation 4}

Tourist : "Piroan Bu es jeruk e?" / "How much does the orange juice cost, mam?" (Asking in Ngoko Javanese)

Resident : "Gangsal ewu, Mas." / "Five thousand, Sir." (Answering in Krama Javanese)

https://doi.org/10.15294/seloka.v6i2.17288. 


\section{5) Conversation 5}

Tourist : "Pesen cilok e Bu lima ngewu ae." / "I would like to order cilok for five thousand rupiah, please." (Ordering in Ngoko Javanese)

Resident : "Gangsal ewu ndamel nopo mawon, Mas?" / "Five thousand? Any particular order?" (Responding in Krama Javanese)

Tourist : "Yok opo Bu?" / "Excuse me? Can you repeat that again?" (Asking in Ngoko Javanese because the tourist does not understand the higher form of Javanese which is Krama)

Resident : "Lima ribu isinya pake apa aja, Mas?" / "Which kinds of cilok do you want to order?" (Responding in Indonesian to be understood by the tourist)

\section{6) Conversation 6}

Tourist : (Window Shopping)

Resident : "Cari apa, Mas Mbak e?" / "What are you two looking for?" (Asking in Indonesian)

Tourist : "Melihat-lihat mawon" / "Just looking, Mam." (Answering in code mix between Indonesian and Krama Javanese)

Resident : "Ditawar juga bisa, Mas." / "They are open for bargain." (Responding in Indonesian)

Those data above are examples of the interaction process between tourists and residents as sellers in KWJ. In the conversation 1,2 , and 6 , the chosen language to be spoken by the resident is Indonesian such as "empat ribu", "es apa", "lima ribu", "cari apa mas", and "ditawar juga bisa". On the other hand, the tourists respond or ask in Krama Javanese. The reason why the resident opted to use Indonesian is that many tourists seem to be interested in the goods. Thus, the resident chooses Indonesian to get the message to the other tourists who are potentially not a Javanese speaker alongside the one who is being spoken to.

In conversation 4 and conversation 5 , the language choice of the resident is Krama Javanese. The resident uses Krama Javanese because the tourist is a Javanese speaker as well, so the tourist can understand the resident, and it is almost mandatory for any Javanese speaker who understands Javanese culture that it is essential to use Krama Javanese to certain people to be seen as polite which is, in this case, is to be polite to a customer.

In conversation 5 , the resident used code-switching between Krama Javanese and Indonesian. This language choice is made because the customer is a local tourist who uses Ngoko Javanese (rougher in nature), so the resident opted to use Krama Javanese (polite form) as a form of respect to the customer. But, the customer did not understand the resident when the resident used Krama Javanese "gangsal ewu, ndamel nopo mawon mas". The choice of language in "lima ribu isinya pake apa aja mas" can be seen as the code switch so the customer can understand the resident's question. It is one way to fulfill the mutual understanding between speakers and listeners. 
From those six conversation data that happened in the shops of KWJ, the language choice used by the residents as sellers is mostly code switching and code mixing between Javanese bot Krama form and Ngoko form and Indonesian.

\section{c. KWJ Alleyways}

Context: About direction and greetings to the residents

\section{1) Conversation 1}

Tourist : "Jembatan kaca ke mana bu ya?" / "Which way to the Glass Bridge?" (Asking in Indonesian)

Resident : "Kiri, Mas." / "To the left." (Answering in Indonesian)

\section{2) Conversation 2}

Tourist : "Permisi.." / "Excuse me.." (Greeting in Indonesian)

Resident : "Monggo" / $\begin{gathered}\text { (Responding in Krama } \\ \text { Javanese) }\end{gathered}$

\section{3) Conversation 3}

$\begin{aligned} \text { Tourist : "Nuwun sewu." / "Excuse } & \\ & \text { me." (Greeting in Krama } \\ & \text { Javanese) } \\ \text { Resident } & \text { "Inggih.." / } \\ & \begin{array}{l}\text { (Responding in Krama } \\ \text { Javanese) }\end{array}\end{aligned}$

\section{4) Conversation 4}

Tourist : (appears to be lost)

Resident : "Lewat sana bisa." / "You can go there." (Informing in Indonesian)

Tourist : "Terima kasih." / "Thank you." (Expressing in Indonesian)

Resident : "Sami-sami." / "Your welcome/" (Responding in Krama Javanese)

\section{5) Conversation 5}

These are the conversation between a foreign tourist and the resident.
Tourist : (Taking pictures with her spouse)
Resident : (Staring at them but say nothing)
Tourist : "It's beautiful here with all the colors." (Initiating conversation with English)
Resident : "Oh.. Yes. Yes." (Responding in simple English)

\section{6) Conversation 6}

Tourist : (Does not know which way to go and about to enter the wrong alleyway)

Resident : "Mister..Mister.." (Calling in English)

Tourist : "Where is the exit?" (Asking in English)

Resident : (Appears to be confused)

Tourist : "Exit." (Simple word in English to help with the message)

Resident : "Exit.. Exit.." Answers by repeating the tourist's word and points to an alleyway leading to the exit)

Conversation 1 until conversation 6 are examples of the interaction process between tourist and the resident of KWJ. In conversation 1, the resident chooses to use Indonesian to answer the tourist's question. The process of language choice is happened due to the tourist asked a question to the resident.

In conversation 2 and conversation 3 , the resident chooses to use Krama Javanese to respond to the tourist's greeting call. Conversation 2 started with 
the tourist greets the resident in Indonesian. For some reason, the resident chooses to use Krama Javanese instead of Indonesian. It is likely because the residents of KWJ are Javanese speakers who are accustomed to responding to greeting calls in Krama Javanese rather than the Indonesian language. Conversation 3 started with the tourist greets the resident in Krama Javanese, "Nuwun Sewu". The resident then responds in kind by using Krama Javanese, "Inggih" which is equivalent to "Yes" or "Please". This is also happened due to the resident's custom, adding the fact that the tourist also speaks in Krama Javanese so the response should be in one. According to Khasanah, in Javanese, the honorific form to respond to the interlocutor (taiwa keigo / addressee honorifics) would be considered polite to use the Javanese Krama form. ${ }^{24}$

In conversation 4, the resident used code shifting from Indonesian to Krama Javanese. The process is happened due to the resident is obligated to help the confused-looking tourist. The resident uses Indonesian, "lewat sana bisa", to point the tourist in the right direction. It is unclear whether the tourist is looking for an exit or a specific place, but the resident assumed the latter by pointing to the most famous spot in KWJ. The resident then responds to the tourist's expression of gratitude with Krama Javanese, "samisami", which is equivalent to "your

24 Ismatul Khasanah, "Constrastive Study of Javanese and Japanese Honorifics" (Dissertation, Graduate School of Education, Hiroshima University, 2012), 110. welcome". The residents of KWJ tend to use Krama Javanese to respond to greeting or expression of gratitude regardless of what language is being used to address them, at least it appears to be so with local and domestic tourists.

In conversation 5, the resident encounters international tourists. A simple English of "yes" was used to respond to the tourist's appraisal to the beautiful color of KWJ, specifically in front of the house of the resident in which the tourist couple is taking pictures. The conversation starts with the tourists realizing that they are being stared at by the resident while taking pictures. The woman tourist then smiles and then says that it is beautiful here because of the various colors. The remark makes the resident a little hesitant to respond but then responded with a simple "yes". It is likely that the resident does not understand the tourist's praise and simply say the easiest English to say which is a simple "yes".

In conversation 6 , the resident uses English to call and to answer the tourist's question. The tourist appears to be lost and almost entered the wrong way. The resident who is watching then calls to him with "mister" which is a common word known to the locals to call international tourists. The tourist then asks about the direction to the exit in English in which the resident did not seem to understand as the tourist did not get any answer. The tourist then uses a simple English word of "exit" to stress the point of the question to the resident in which the resident understands and proceeds to point the direction with his finger while saying 
"exit... exit". It shows that the language choice process did not work well due to the English language barrier, such as not understanding English. By lowering the barrier to a bare minimum by using universal English words that anybody will understand, the language choice process can continue.

From the six examples of conversations between the residents and the tourists, the writer finds that the conversations among the tourists and the residents generally revolve around greeting, responding to the expression of gratitude, and a simple directional question. Although the conversations are generally short and quick, those interactions are enough to make language choice phenomena happen.

\section{The Process of Interaction between KWJ Residents and Tourists}

The interaction between the tourists and $\mathrm{KWJ}$ residents is generally happening in the ticket booth and the shops. The residents who are has nothing to do with those places tend to be passive in their approach to the tourist. Most of the interactions are initiated by the tourists as the resident as a seller does not immediately call to a tourist who is a potential buyer even after the tourist shows signs of interest in the goods. Though with the process of interaction or with a direct conversation, it can be a means to improve communication skills. ${ }^{25}$

\footnotetext{
${ }^{25}$ Dewi Christa Kobis, "The Effectiveness of Tourist Hunting Project in Improving Students' English Communication Skills," OKARA: Jurnal Bahasa dan Sastra 13, no. 1 (May 31, 2019): 65-80,
}

In the observation phase, the writer found that the sellers tend to be silent as the tourists pass by their shops if they do not show any sign of interest in their goods. Even when the tourists show some interest in the goods that the sellers are selling, such as stopping and seeing the shops from a distance of more than a meter long, the sellers also shy away from engaging the tourists in conversation. Only when the tourists are showing a strong sign of interest by walking towards the shops and stop right at the stall, the sellers will initiate the conversation in Indonesian if the tourists do not start one.

Meanwhile, the tourists do not always use Indonesian to initiate the interaction with the sellers. Although some choose to use Indonesian, local tourists who originated from Malang tend to use Ngoko or Krama Javanese. The sellers then might respond to the tourists with Indonesian or Krama Javanese. When the tourist can speak Ngoko Javanese but cannot understand Krama Javanese, the seller uses Indonesian instead. For expressing gratitude, the sellers tend to use Krama Javanese even though the tourists are using Indonesian.

There are no more than a few interactions between the residents and the international tourists as the language barrier is too high. International tourists tend not to immediately engage in an interaction unless there is a particular cause where international tourists cannot help but interact with the residents. For example, a tourist is initiating the

https://doi.org/10.19105/ojbs.v13i1.2262. 
interaction because she realized that she was being stared at the whole time when she was taking pictures by a certain female resident. In a case similar to this, the international tourists tend to only greet with "hello" in which the resident responds with "hai" and that is when the conversation stops. If any international tourists choose to say a longer sentence which is not a question, the resident tends to answer them with a simple "yes".

In a particular condition, the residents can be the one to initiate a simple interaction with international tourists. For example, when a tourist appears to be lost and enters a wrong alleyway, a resident might call the tourist, and then an interaction happens. The writer is lucky enough to find such an encounter when a tourist from London is about to enter a wrong alleyway a resident called and stopped him. Then the tourist asked the resident about the exit in which the resident did not understand. The tourist then focused on the noun "exit" whom he was looking for, and the resident pointed him into an alleyway while repeating the tourist's "exit" several times. Other than a few rare instances like that, international tourists tend to keep for themselves and rarely ask about direction even when there are very few directional markers in KWJ, and they are all written in Indonesian.

\section{Conclusion}

As the owner and the tourism spot manager, residents of Kampung WarnaWarni Jodipan Malang are surprisingly passive in their interaction with the tourist.
It can be seen from the interaction data where most of the residents only use short sentences. For example, residents in the ticket booth, shops, and alleyways only interact with tourists for a mere obligation or courtesy. It can be said the residents are passive because those are the place where the interaction between residents and tourists mostly happen. The residents' choice of language toward tourists is mostly done in code mix and code shift, between Javanese Krama and Ngoko, and Indonesian. In contrast, the interaction with international tourists in English is rare; the residents can communicate even though it is only happening in greetings and simple directional information.

\section{References}

Apriliyani, Nurul, and Fathur Rokhman. "Strategi Pilihan Bahasa Pengusaha Industri di Kecamatan Ajibarang Kabupaten Banyumas." Seloka: Jurnal Pendidikan Bahasa dan Sastra Indonesia 5, no. 2 (2016): 184-91. https://doi.org/10.15294/seloka.v5i2. 13082.

Chaer, Abdul, and Leonie Agustina. Sosiolinguistik Perkenalan Awal. Revision. Jakarta: PT Rineka Cipta, 2010.

Crystal, David. A Dictionary of Linguistics and Phonetics. New Jersey: John Wiley \& Sons, 2011.

Ervin-Tripp, S. "Sociolinguistics Rules of Address." In Sociolinguistics, by J.B. Pride and Janet Holmes. London: Penguin Books, 1972.

Fasold, Ralph. The Sociolinguistics of Society. Oxford: Basil Blackwell Ltd, 1984. 
Kelurahan Jodipan. "Peta Wilayah Kelurahan Jodipan." Accessed October 8, 2020. https://keljodipan.malangkota.go.id/ profil/peta-wilayah-kelurahanjodipan/.

Kesuma, Tri Mastoyo Jati. Pengantar (Metode) Penelitian Bahasa. Yogyakarta: Carasvatibooks, 2007.

Khasanah, Ismatul. "Constrastive Study of Javanese and Japanese Honorifics." Dissertation, Graduate School of Education, Hiroshima University, 2012.

Kholidah, Umi. "Pemertahanan Bahasa Jawa pada Interaksi Siswa dan Guru dalam Pembelajaran Kajian Sosiolinguistik di MTS Al-Hikmah Pasir Demak." Ranah: Jurnal Kajian Bahasa 4, no. 2 (2015): 105-14. https://doi.org/10.26499/rnh.v4i2.27.

Kholidah, Umi, and Haryadi. "Wujud Pilihan Kode Tutur Mahasiswa Aceh pada Ranah Pergaulan di Semarang." Seloka: Jurnal Pendidikan Bahasa dan Sastra Indonesia 6, no. 2 (2017): 208-17. https://doi.org/10.15294/seloka.v6i2. 17288.

Kobis, Dewi Christa. "The Effectiveness of Tourist Hunting Project in Improving Students' English Communication Skills." OKARA: Jurnal Bahasa dan Sastra 13, no. 1 (2019): 65-80. https://doi.org/10.19105/ojbs.v13i1.2 262.

Labov, William. Sociolinguistics Patterns. Philadelphia: University of Pennsylvania Press, 1972.

Mardikantoro, Hari Bakti. "Bentuk Pergeseran Bahasa Jawa Masyarakat Samin dalam Ranah Keluarga." LITERA 11, no. 2 (2012): 204-15.

https://doi.org/10.21831/ltr.v11i2.10 62.

Mardikantoro, Hari Bakti. "Pilihan Bahasa Masyarakat Samin dalam Ranah Keluarga." Jurnal Humaniora 24, no.
3 (2012):

345-57.

https://doi.org/10.22146/jh.1376.

Moleong, Lexy J. Metodologi Penelitian Kualitatif. Bandung: Remaja Rosdakarya, 2014.

Mustikawati, Dyah Atiek. "Alih Kode dan Campur Kode antara Penjual dan Pembeli (Analisis Pembelajaran Berbahasa melalui Studi Sosiolinguistik)." Jurnal Dimensi Pendidikan dan Pembelajaran 2, no. 2 (2016): 23-32. https://doi.org/10.24269/dpp.v2i2.15 4.

Ngalim, Abdul. Sosiolinguistik Suatu Kajian Fungsional dan Analisisnya. Surakarta: PBSID FKIP UMS, 2013.

Niswa, Lailatun, and Mukhlish. "Pilihan Bahasa dalam Masyarakat Multilingual di Kemujan Karimunjawa Jepara." Caraka 3, no. 2 (2017): 110-26. https://doi.org/10.30738/caraka.v3i2. 1893.

Putri, Nandita Wana. "Pergeseran Bahasa Daerah Lampung pada Masyarakat Kota Bandar Lampung." PRASASTI: Journal of Linguistics 3, no. 1 (2018): 83-97. https://doi.org/10.20961/prasasti.v3i 1.16550 .

Rokhman, Fathur. Sosiolinguistik: Suatu Pendekatan Pembelajaran Bahasa dalam Masyarakat Multikultural. Yogyakarta: Graha IImu, 2013.

Sholihatin, Anis. "Pemilihan Kode pada Masyarakat Keturunan Arab di Noyontaan, Kota Pekalongan: Kajian Sosiolinguistik." Thesis, Universitas Diponegoro, 2008.

Wardhani, Pramika. "Wujud Pilihan Bahasa dalam Ranah Keluarga pada Masyarakat Perumahan di Kota Purbalingga." KREDO : Jurnal IImiah Bahasa dan Sastra 1, no. 2 (2018): 91-105. https://doi.org/10.24176/kredo.v1i2. 2147. 
Widianto, Eko, and Ida Zulaeha. "Pilihan Bahasa dalam Interaksi Pembelajaran Bahasa Indonesia bagi Penutur Asing." Seloka: Jurnal Pendidikan Bahasa dan Sastra Indonesia 5, no. 2 (2016): 124-35. https://doi.org/10.15294/seloka.v5i2. 13074.

Wijana, I. Dewa Putu, and Muhammad Rohmadi. Sosiolinguistik: Kajian Teori dan Analisis. Yogyakarta: Pustaka Pelajar, 2013. 